\title{
The Growth of Lemongrass (Cymbopogon nardus (L.) RENDLE) in Agroforestry and Monoculture System on Post-Coal Mining Revegetation Land
}

\author{
Anna Juliarti ${ }^{1,2}$, Nurheni Wijayanto ${ }^{2 *}$, Irdika Mansur ${ }^{2}$, Trikoesoemaningtyas ${ }^{3}$ \\ ${ }^{1}$ Departement of Forestry, Faculty of Forestry, Lancang Kuning University, Yos Sudarso Street \\ KM 8 Pekanbaru, Indonesia 28265, and Graduate Program of Silviculture, Faculty of Forestry and Environment, IPB \\ University, Academic Ring Road, Campus IPB Dramaga, Bogor, Indonesia 16680 \\ ${ }^{2}$ Department of Silviculture, Faculty of Forestry and Environment, IPB University, Academic Ring Road, \\ Campus IPB Dramaga, Bogor, Indonesia 16680 \\ ${ }^{3}$ Department of Agronomy and Horticulture, Faculty of Agriculture, IPB University, Meranti Road, \\ Campus IPB Dramaga, Bogor, Indonesia 16680
}

Received September 1, 2020/Accepted December 30, 2020

\begin{abstract}
Lemongrass (Cymbopogon nardus) as cover crop was suitable planted with agroforestry and monoculture system on post-coal mining revegetation land. The study investigated the influence of planting system, varieties, and plant spacing against the lemongrass growth on post-coal mining land under the agroforestry and monoculture system. Two lemongrass varieties were planted under on both planting systems. The growth variables of lemongrass measured were the tillers number per clump, leaf length, and canopy width. The results showed that the planting system and lemongrass varieties were able to increase the growth oflemongrass. Plant spacing treatment was able to increase the tillers number per clump. The agroforestry system was able to increase leaflength and canopy width of lemongrass. However, monoculture system was able to increase the tillers number per clump. The G2 variety had better growth on all measured variables either in agroforestry and monoculture system compared to Sitrona 2 Agribun variety. The plant spacing of $0.5 \mathrm{~m} \times 0.5 \mathrm{~m}$ had greater tillers number per clump of lemongrass compared to plant spacing of $1 \mathrm{~m} \times 1 \mathrm{~m}$.
\end{abstract}

Keywords: lemongrass, agroforestry, monoculture, post-coal mining

*Correspondence author, email:nurheniw@gmail.com,tel.+62-251-8621677,fax+62-251-8621256

\section{Introduction}

Coal mining is part of open-pit mining through forest clearing, land surfaces opening, dredging, and stockpiling. Mining activities affect environmental qualities, including soil physical, chemical, and biological damage (Soendjoto et al., 2014; Setyaningsih et al., 2018; Lestari et al., 2019). Physically, soil becomes very compact due to heavy equipment activity during mining (Setiadi \& Adinda, 2013) or even crumbly which tends to cause land slides, besides microclimate change (Zulkarnain et al., 2014). Chemically, soil is suffered from acidity, decrease organic matter and macronutrient content, as well as increased micronutrient content (Setyaningsih et al., 2020). Biologically, soil damage decreases the biodiversity of both micro and macroorganism.

High soil acidity or low $\mathrm{pH}$ condition allows high amounts of micro-element release, such as $\mathrm{Al}, \mathrm{Fe}$, and $\mathrm{Mn}$. These elements will inhibit the plant growth and uptake of water and nutrients, when available in excessive amount
(Matsumoto et al., 2017). High level of Al in soil affects the availability of $\mathrm{P}$ (phosphorus) and $\mathrm{N}$ (nitrogen) nutrient (Lubis et al., 2015). Toxic Al is the most significant threat to plant survival in acidic soils (Rahman et al., 2018). Plant function and land production will decrease, when the plant growth is disturbed, causing the local ecosystem structure damage (Allo, 2016). Soil compaction is one of the major physical factors that can change soil structure, and productivity (Mueller et al., 2010), besides an affecting plant growth, and depth of plant root penetration (Shukor et al., 2015). Solid soil reduces pore space between soil particles, limiting water and gas exchange (Nawaz et al., 2013).

Revegetation is one way to reclaim degraded postmining land. Revegetation is aimed to increase the fertility of degraded mined land (Mensah, 2015; Buta et al., 2019), through increased soil organic matter content, available nutrients, CEC, biological activity, and soil physical condition (Mensah, 2015). A revegetation model suitable to utilize land among the main crop is agroforestry. 
Agroforestry is an integrated land concept of using a combination of agriculture and forestry with various biomass productions, besides environmentally and socially conservative (Suryani \& Dariah, 2012; Kaur et al., 2017; Cardinael et al., 2017; Tarigan et al., 2019).

The success of agroforestry system depends on the selection of shade-tolerant species (Caron et al., 2019). Lemongrass (Cymbopogon nardus (L.) RENDLE) is chosen as an intercropping plant among the main plants because it has the following characteristics: (1) fast-grow (Sukamto et al., 2011); (2) deep abundant roots is on hold the soil (Sukamto et al., 2011; Sulaswatty et al., 2019); (3) un-favored by livestock (Pandey \& Singh, 2012; Bisoi et al., 2017); (4) able to live in the $\mathrm{pH}$ soil range of 57 , sandy loam or clay (Sukamto et al., 2011); (5) widely adaptable; (6) able to resist erosion; (7) quickly forms canopy; (8) producing essential oil, and social benefits (Pandey et al., 2014; Verma et al., 2014; Maiti \& Prasad, 2016; Juliarti et al., 2020), and (9) are non-toxic to staple plants. Those criterion are suitable to be utilized as a post-mining revegetation plant which usually has acid soils, lack of top-soil, and abundant soil density.

In this study, revegetation carried out with agroforestry system on post-mining land is expected to optimize land use functions as environmental, and ecosystem quality improvement to increase land and crop productivity. Ecologically, revegetation can minimize degradation which causes soil erosion and changes in physical and chemical properties. Economically, degraded land can be converted into productive land by growing food crops among the main crops.

Selection of lemongrass varieties as intercrops in agroforestry system on post-coal mining areas is important to achieve production, social and ecological objectives. The lemongrass G2 (discovered in 1992) and Sitrona 2 Agribun (discovered in 2015) variety are superior varieties cultivated by the Institute of Medicinal and Aromatic Plant Research, Ministry of Agriculture Affairs, Indonesia (Rosman, 2012; MoA, 2016). These two varieties have never been studied in post-coal mining land with agroforestry and monoculture systems.

Generally, several studies reported that lemongrass could be planted on laboratory scale, and infertile mineral soils in monoculture system (Rosman, 2012; Anwar et al., 2017; Sulaswatty et al., 2019), but has never been planted on postmining areas in Agroforestry system. The study investigated and compared the growth of lemongrass varieties planted on post-coal mining revegetation land in agroforestry and monoculture system. This study also gives a suggestion, which varieties should be suitable utilized for revegetation on post-mining area.

\section{Methods}

Location and period The study activities were carried out in the nursery area for lemongrass seedling preparation and planting on the post-coal mining revegetation land (1.1 ha) of PT Bukit Asam (Inc.), Muara Enim, South Sumatera, Indonesia (Figure 1). This post-coal mining revegetation land is in other use area (OUA) status, and will be planted based on agroforestry system (cajuput and lemongrass). The monoculture area was planted with lemongrass monoculture and is located beside to the agroforestry area. The study was conducted for 12 months from April 2017 to March 2018.

Seedling and media preparation Lemongrass clump was obtained from The Institute for Medicinal and Aromatic Plant Research, Cimanggu, Bogor, Indonesia. There were two varieties of lemongrass tiller, i.e. G2 and Sitrona 2

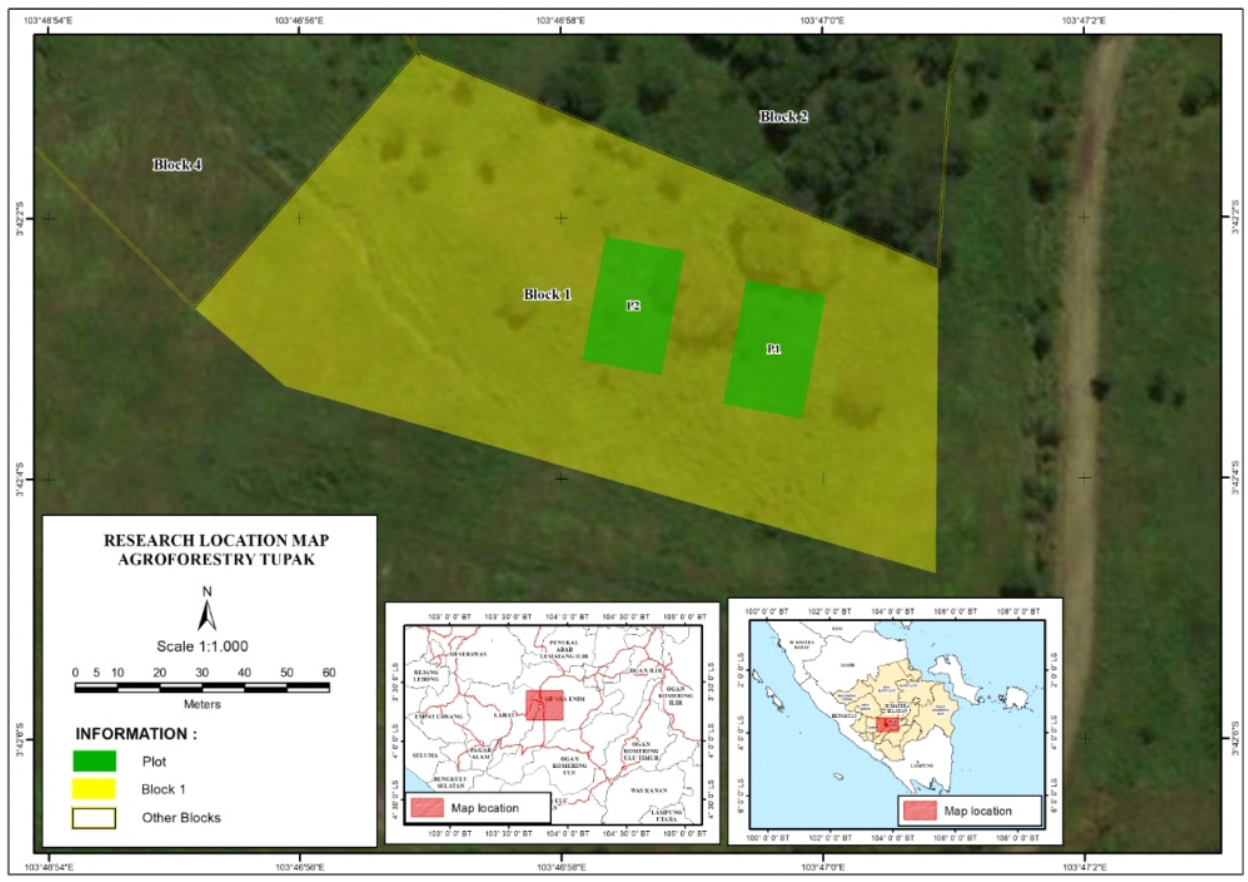

Figure 1 Study location (S03 $42^{\prime} 03.6^{\prime \prime}$ and E103 $\left.47^{\prime} 01.2^{\prime \prime}\right)$. 
Agribun variety. Before planting in polybag, lemongrass seeds were selected and separated from the clumps. Each polybag contains one lemongrass. Lemongrass leaves were cut to an average height of $25 \mathrm{~cm}$ from stem base. The average canopy width was $5 \mathrm{~cm}$. Lemongrass tiller was planted in a polybag $(10 \mathrm{~cm} \times 15 \mathrm{~cm})$ with red yellow podsolic soil as media. Seedlings were maintained for two months at the nursery.

Land and planting preparation Land preparation was carried on 2 areas, namely revegetation area with 1.5 years old cajuput and lemongrass on agroforestry system and lemongrass on monoculture area. Plant spacing between the cajuput was $4 \mathrm{~m} \times 2 \mathrm{~m}$, while between cajuput and lemongrass was $1 \mathrm{~m}$. Among cajuput trees, lemongrass seedling was planted with size $2 \mathrm{~m} \times 2 \mathrm{~m}$. Lemongrass was planted with spacing of $0.5 \mathrm{~m} \times 0.5 \mathrm{~m}$ and $1 \mathrm{~m} \times 1 \mathrm{~m}$ (Figure 2). The study area (agroforestry and monoculture system) had 24 planted sample units from 2 lemongrass varieties, namely G2 and Sitrona 2 Agribun variety. The lemongrass planting hole used was $20 \mathrm{~cm} \times 20 \mathrm{~cm} \times 20 \mathrm{~cm}$.
Plant growth parameters Growth parameters measured were tillers number per clump, leaf length, and canopy width. Measurement of the tillers number per clump was carried out by counting the tillers number per clump of sample plants (Figure 3a). The lemongrass length leaf was measured from the longest leaves (Figure 3b). The lemongrass canopy width is the average of the longest and shorted lemongrass canopy (Figure 3c). Plant growth observations were carried out at $0,6,9$, and 12 months after planting in the field.

Experimental design and data analysis The study design was a split-plot randomized block design for 8 treatments consisting of planting system which are agroforestry (P1) and monoculture (P2); lemongrass varieties which are $\mathrm{G} 2$ variety (V1) and Sitrona 2 Agribun variety (V2), and also plant spacing which are $0.5 \mathrm{~m} \times 0.5 \mathrm{~m}(\mathrm{~J} 1)$ with 25 lemongrass plants and $1 \mathrm{~m} \times 1 \mathrm{~m}(\mathrm{~J} 2)$ with 9 lemongrass plants (Figure 4). Each treatment was repeated 3 times. All data were statistically analyzed use SAS 9.1 software program and Microsoft Excel to determine significant



Note: $\oplus=$ cajuput, $\sqrt{ }=$ lemongrass, $\sqrt{ }-\sqrt{ }=$ plant spacing $0.5 \mathrm{~m} \times 0.5 \mathrm{~m}(\mathrm{a}) ; 1 \mathrm{~m} \times 1 \mathrm{~m}(\mathrm{~b})$.

Figure 2 Cajuput and lemongrass agroforestry design.

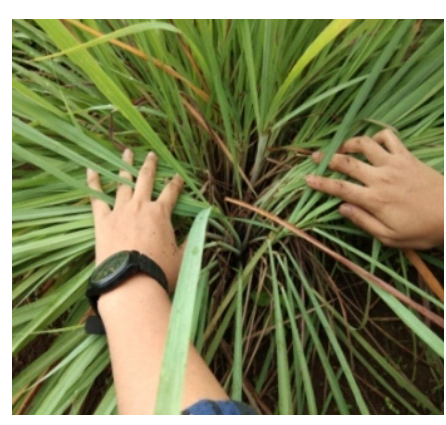

(a)

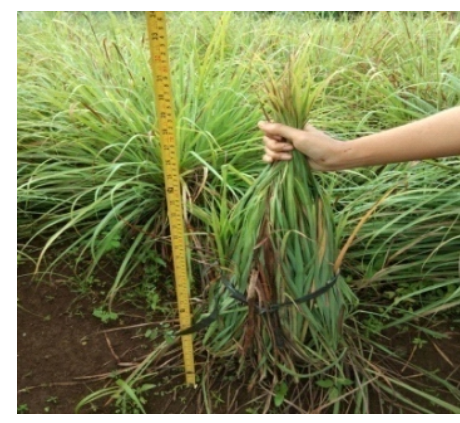

(b)

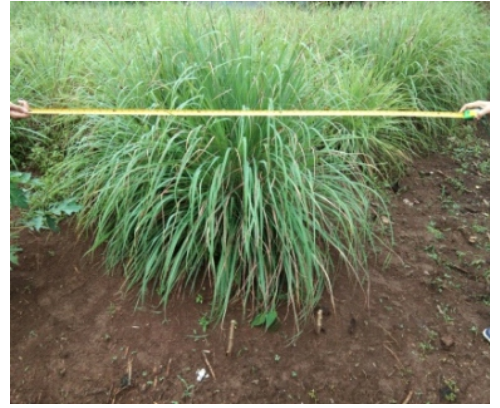

(c)

Figure 3 Measurement of the tillers number per clump (a), leaf length (b), and canopy width (c) of lemongrass. 


\begin{tabular}{|c|c|c|c|}
\hline \multicolumn{4}{|c|}{ P1 } \\
\hline \multicolumn{2}{|c|}{ V1 } & \multicolumn{2}{c|}{ V2 } \\
\hline J1 & J2 & J2 & J1 \\
\hline 1 & 2 & 3 & 2 \\
\hline 2 & 1 & 2 & 3 \\
\hline 3 & 3 & 1 & 1 \\
\hline
\end{tabular}

\begin{tabular}{|c|c|c|c|}
\hline \multicolumn{4}{|c|}{ P2 } \\
\hline \multicolumn{2}{|c|}{ V2 } & \multicolumn{2}{c|}{ V1 } \\
\hline J2 & J1 & J1 & J2 \\
\hline 2 & 1 & 1 & 3 \\
\hline 3 & 2 & 3 & 1 \\
\hline 1 & 3 & 2 & 2 \\
\hline
\end{tabular}

Figure 4 Layout of lemongrass research design.

different among treatments.

\section{Results and Discussion}

Soil properties and lemongrass suitability criteria The post-coal mining revegetation land was characterized as the sandy loam soil (followed the criteria for lemongrass, namely sandy loam soil) with $1.1^{\mathrm{GCC}-1}$ bulk density (followed the criteria for lemongrass with $\left.1.1-1.6^{\mathrm{GCC}-1}\right), 2.35^{\mathrm{GCC}-1}$ particle density, 59.19 total pore space and 3.17 hour $^{-1}$ permeability. The land also had the chemical properties, such as $\mathrm{pH} 6.02$ (followed the criteria for lemongrass with 5.57), total $\mathrm{N}$

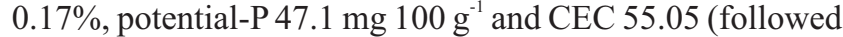
the criteria for lemongrass with $>17$ ) (Table 1). The physical and chemical properties of the revegetation land were still within range of lemongrass suitability criteria. The post-coal mining land in East Kutai, East Kalimantan has several soil characteristics that are almost the same as soil pH (4.10-6.46), total $N(0.08-0.21)$, and potential $P(35.2-77.2$ $\mathrm{mg} 100 \mathrm{~g}^{-1}$ ) (Mashud \& Manaroinsong, 2014).

Lemongrass growth Lemongrass growth was measured 4 times, i.e., 0, 6, 9, and 12 months, by measuring the tillers number per clump, leaf length, and canopy width. The treatment of planting system, lemongrass varieties, and plant spacing showed different response on lemongrass growth. The planting systems and lemongrass variety treatment were significantly different $(p<0.05)$ on all variables (Table 2 and Table 3 ). The plant spacing treatment was significantly different $(p<0.05)$ on tillers number per clump (Table 4 ). The combination treatments of planting system, lemongrass variety, and plant spacing were insignificantly different $(p>0.05)$ on all variables.

Plant growth was influenced by genetic and environmental factors. Gene differences in an individual will affect the ability to adapt and change during development (Susanto \& Baskorowati, 2018). The growth of lemongrass is affected by the land suitability, climate, altitude, light intensity, and soil fertility (Sujianto et al., 2018). The average of lemongrass growth in planting systems, lemongrass variety, and plant spacing treatment are presented on Table 2, Table 3, and Table 4 . The agroforestry planting system was significantly different $(p<0.05)$ on lemongrass leaf length $(108.15 \mathrm{~cm})$ and canopy width $(91.49 \mathrm{~cm})$ compared to monoculture with $102.07 \mathrm{~cm}$ leaf length and $81.86 \mathrm{~cm}$ canopy width, respectively (Table 2). The leaf length and land coverage are important morphological characters that are directly related to crop yields. Lemongrass that grew in agroforestry system was more fertile than monoculture system. The same result was reported by Chandrawanshi (2016). Light intensity level affects the canopy width. The lower the light intensity, the greater the canopy width formed (Suci \& Heddy, 2018). The success of agroforestry system depends on the selection of shade tolerant species and efficient plants that can properly absorb solar radiation due to having a greater capacity for acclimatization and adaptation (Caron et al., 2019). Historically, agroforestry system has been widely implemented to achieve sustainable agricultural and decrease the negative effects of agriculture (e.g. water pollution, biodiversity loss, desertification, erosion, and soil degradation) without compromising crop productivity (Torralba et al., 2016; Artru et al., 2017).

The average tillers number per clump, leaf length and canopy width of lemongrass G2 variety $(40.32,129.54 \mathrm{~cm}$, and $101.45 \mathrm{~cm}$, respectively) were higher than the Sitrona 2 Agribun variety $(17.59,80.67 \mathrm{~cm}$, and $71.91 \mathrm{~cm}$, respectively) (Table 3 ). The tillers number per clump, leaf length, and canopy width in this study were higher than the study results of the MoA (2016) and Syukur \& Trisilawati (2019). This showed that the G2 variety is more suitable for planting on post-mining revegetation areas both in agroforestry and monoculture system than Sitrona 2 Agribun variety (Figure 5, Figure 6, and Figure 7). The average of tillers number per clump should be 63.7 tillers, leaf length should be $76.1 \mathrm{~cm}$, and canopy width should be $108.7 \mathrm{~cm}$ with the $\mathrm{G} 2$ variety in monoculture system should be planted on a fertile land in West Sumatera with various altitudes (Suryani \& Nurmansyah, 2013). In another study, the average of tillers number per clump (32.28 tillers), leaf length $(74.35 \mathrm{~cm})$ with the $\mathrm{G} 2$ variety in monoculture system should be planted on a fertile land in North Sumatera (Nurdianti et al., 2019). Generally, several studies have reported that monoculture system produced higher growth 
Table 1 Soil properties on revegetation land and lemongrass suitability criteria

\begin{tabular}{|c|c|c|}
\hline Variable & Revegetation land & Preferences for lemongrass \\
\hline Texture & clay & Sandy loam \\
\hline Sand (\%) & 15.79 & - \\
\hline Dust (\%) & 27.53 & - \\
\hline Clay (\%) & 56.68 & - \\
\hline $\mathrm{pH}$ & & $5.5-7 *$ \\
\hline $\mathrm{H}_{2} \mathrm{O}$ & 6.02 & - \\
\hline $\mathrm{CaCl}_{2}$ & 5.41 & - \\
\hline C-org (\%) & 12.41 & $2-3 *$ \\
\hline Total N (\%) & 0.17 & $0.21-0.5^{* *}$ \\
\hline $\mathrm{C} / \mathrm{N}$ ratio & 72.97 & - \\
\hline Available $\mathrm{P}_{2} \mathrm{O}_{5}(\mathrm{ppm})$ & 95.14 & $16-25^{*}$ \\
\hline $\mathrm{P}_{2} \mathrm{O}_{5}$ Potential $\left(\mathrm{mg} 100 \mathrm{~g}^{-1}\right)$ & 47.10 & - \\
\hline $\mathrm{K}_{2} \mathrm{O}$ Potential $\left(\mathrm{mg} 100 \mathrm{~g}^{-1}\right)$ & 75.20 & $>1 *$ \\
\hline $\mathrm{Ca}\left(\mathrm{mol} \mathrm{kg}^{-1}\right)$ & 8.20 & - \\
\hline $\mathrm{Mg}\left(\mathrm{mol} \mathrm{kg}{ }^{-1}\right)$ & 8.10 & - \\
\hline $\mathrm{K}\left(\mathrm{mol} \mathrm{kg}{ }^{-1}\right)$ & 0.51 & - \\
\hline $\mathrm{Na}\left(\mathrm{mol} \mathrm{kg}^{-1}\right)$ & 0.38 & - \\
\hline $\mathrm{CEC}$ & 55.05 & $>17 *$ \\
\hline Bulk Density $\left({ }^{\mathrm{GCC}-1}\right)$ & 1.10 & $1.1-1.6^{* *}$ \\
\hline Particle density $\left({ }^{\mathrm{GCC}-1}\right)$ & 2.35 & - \\
\hline Total pore space $(\%)$ & 59.19 & - \\
\hline Permeability $\left(\right.$ hour $^{-1}$ ) & 3.17 & - \\
\hline
\end{tabular}

Table 2 The average of tillers number per clump, leaf length, and canopy width of lemongrass on two planting systems

\begin{tabular}{cccc}
\hline $\begin{array}{c}\text { Treatment } \\
\text { Planting system }\end{array}$ & $\begin{array}{c}\text { Tillers number } \\
\text { per clump }\end{array}$ & $\begin{array}{c}\text { Variables } \\
\text { Leaf length }(\mathrm{cm})\end{array}$ & Canopy width (cm) \\
\hline Agroforestry (P1) & $28.47^{\mathrm{b}}$ & $108.15^{\mathrm{a}}$ & $91.49^{\mathrm{a}}$ \\
Monoculture (P2) & $29.45^{\mathrm{a}}$ & $102.07^{\mathrm{b}}$ & $81.86^{\mathrm{b}}$ \\
\hline
\end{tabular}

Note: Values followed by similar letter in a column are insignificantly different based on Duncan analysis at $5 \%$ of $\alpha$.

Table 3 The average of tillers number per clump, leaf length and canopy width treated on lemongrass variety

\begin{tabular}{lccc}
\hline \multicolumn{1}{c}{ Treatment } & $\begin{array}{c}\text { Variables } \\
\text { Lemongrass variety }\end{array}$ & $\begin{array}{c}\text { Tillers number } \\
\text { per clump }\end{array}$ & $\begin{array}{c}\text { Leaf length (cm) } \\
\text { Canopy width (cm) }\end{array}$ \\
\hline G2 Variety (V1) & $40.32^{\mathrm{a}}$ & $129.54^{\mathrm{a}}$ & $101.45^{\mathrm{a}}$ \\
Sitrona 2 Agribun Variety (V2) & $17.59^{\mathrm{b}}$ & $80.67^{\mathrm{b}}$ & $71.91^{\mathrm{b}}$ \\
\hline
\end{tabular}

Note: Values followed by similar letter in a column are insignificantly different based on Duncan analysis at $5 \%$ of $\alpha$.

Table 4 The average of tillers number per clump of the lemongrass plant is treated on plant spacing

\begin{tabular}{cc}
\hline Plant spacing & Tillers number per clump \\
\hline $0.5 \mathrm{~m} \times 0.5 \mathrm{~m}(\mathrm{~J} 1)$ & $33.79^{\mathrm{a}}$ \\
$1 \mathrm{~m} \times 1 \mathrm{~m}(\mathrm{~J} 2)$ & $24.12^{\mathrm{b}}$ \\
\hline
\end{tabular}

Note: Values followed by similar letter in a column are insignificantly different based on Duncan analysis at $5 \%$ of $\alpha$. 


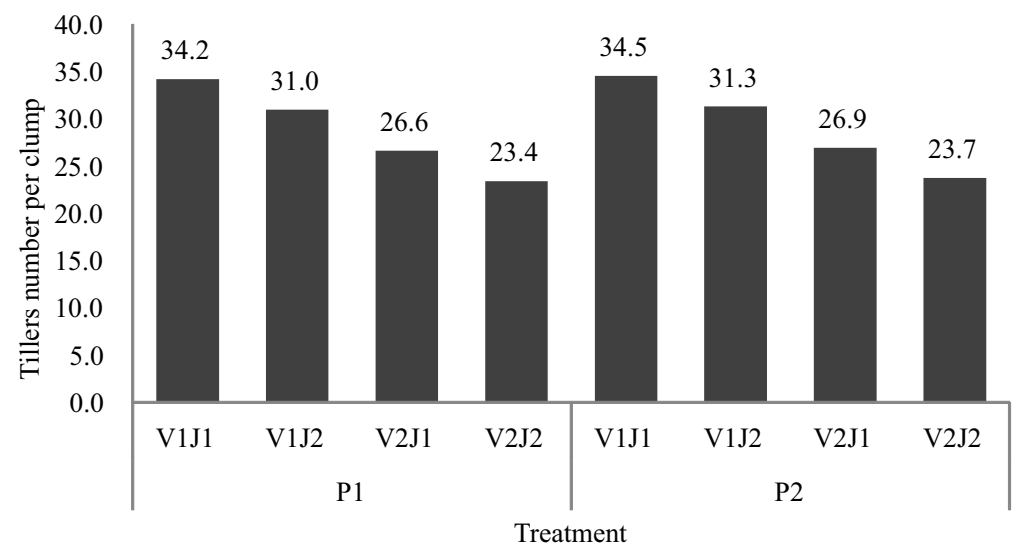

Figure 5 Tillers number per clump of lemongrass from the combination of treatments.

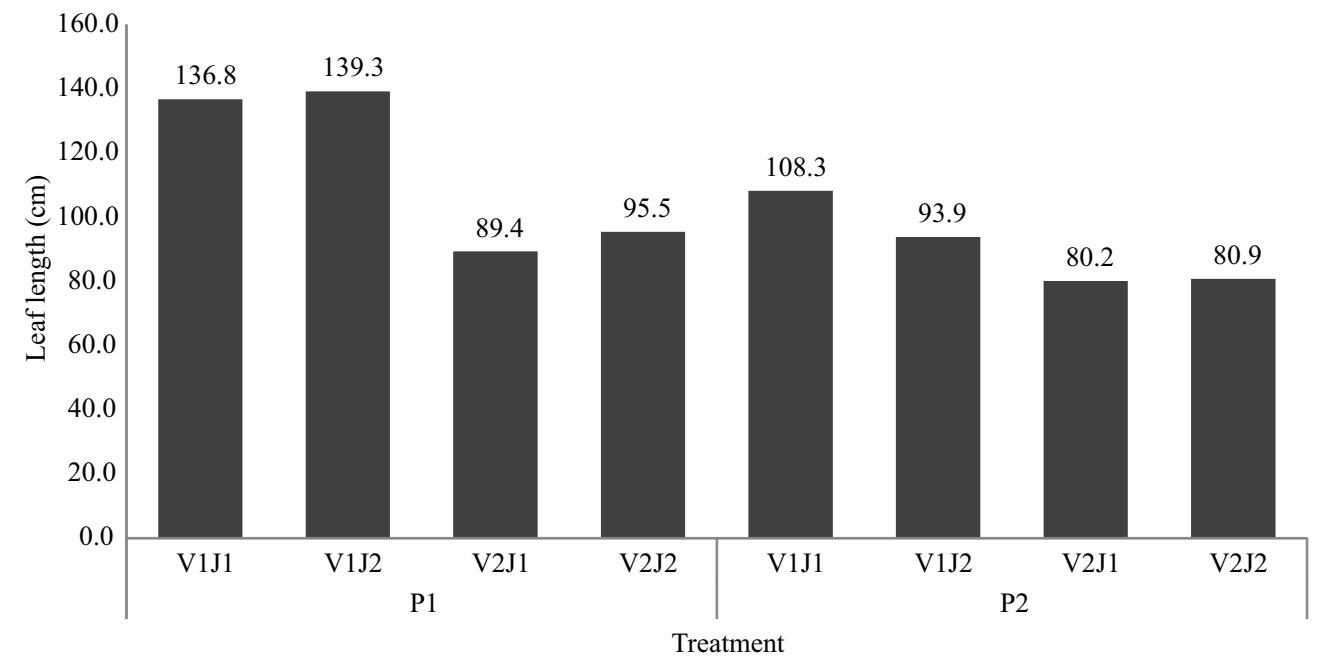

Figure 6 Leaflength of lemongrass from the combination of treatments.

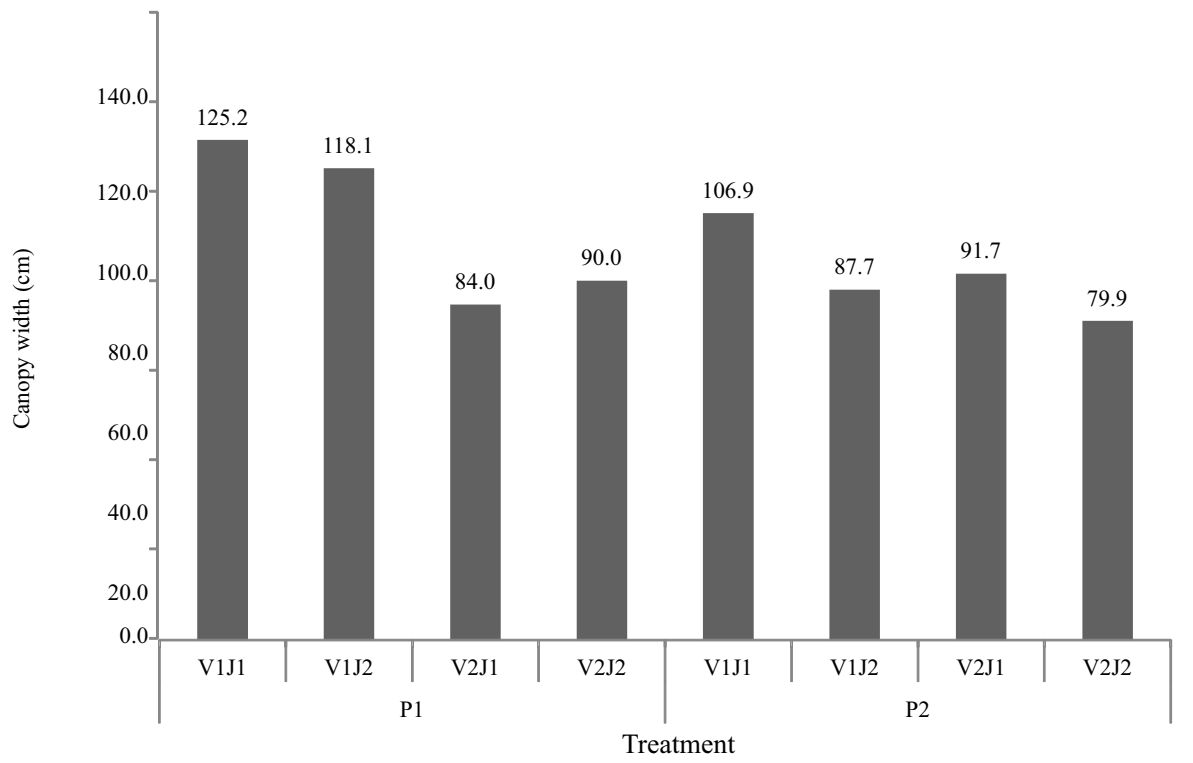

Figure 7 Canopy width of lemongrass from the combination of treatments. 
than agroforestry system (Ningrum et al., 2018; Azizah et al., 2019). However, in this study, the agroforestry system produced higher leaf length and canopy width than the monoculture system. The combination of lemongrass and cajuput in agroforestry caused interaction and competition. Abundant light, nutrients, water and space in agroforestry will improve the growth of all plant components that leads to reduce growth of other crops (Hairiah et al., 2002). To minimize the impact of competition, agroforestry land management can be carried out by setting the spacing, planting system, and selection of annual crops. In addition to genetic factors, environmental factors such as low doses of fertilizer, light, water, as well as lack of management also affect the growth of lemongrass. Based on field observation, cajuput canopy ( 2.5 years old) did not form a wide canopy and dominated space that did not affect to the growth of lemongrass.

Monoculture system produced a higher tillers number per clump (29.45) than agroforestry system (28.47) (Table 2). Based on field observation, monoculture system had higher tillers number per clump than agroforestry system, but smaller stem diameter than agroforestry system. In monoculture system, lemongrass grew faster toward the sides (tillers number per clump) than upward growth (leaf length and canopy width).

The average tillers number per clump of lemongrass on plant spacing treatment is presented on Table 4 . The plant spacing of $0.5 \mathrm{~m} \times 0.5 \mathrm{~m}$ was significantly different $(\mathrm{p}<0.05)$ on the tillers number per clump of lemongrass (33.79 tillers) compared to plant spacing $1 \mathrm{~m} \times 1 \mathrm{~m}$ (24.12 tillers). In several studies, the wider the plant spacing, the greater tillers number per clump (Daswir et al., 2009; Kebede \& Chala, 2016; Hamed et al., 2017). However, in this study, the highest tillers number per clump were obtained from at plant spacing $0.5 \mathrm{~m} \times 0.5 \mathrm{~m}$ compared to plant spacing $1 \mathrm{~m} \times 1 \mathrm{~m}$. This was suspected that limited space could stimulate the growth of new clumps faster than other growth variables, namely leaf length and canopy width. Base on field observation, although the tillers number per clump of lemongrass at plant spacing of $0.5 \mathrm{~m} \times 0.5 \mathrm{~m}$ was higher than plant spacing of $1 \mathrm{~m} 1 \mathrm{~m}$, the diameter of plant spacing with $0.5 \mathrm{~m} \times 0.5 \mathrm{~m}$ is smaller than $1 \mathrm{~m} \times 1 \mathrm{~m}$. Plant growth will be faster when the spacing is tight and the canopy does not intersect (Simarangkir, 2000). This is due to limited plant evaporation and light exposure, causing high water content in the soil. The condition supports the plants to induce photosynthesis process, therefore increasing the plant grow (Simarangkir, 2000).

\section{Conclusion}

Lemongrass (Cymbopogon nardus (L.) RENDLE) is suitable planted in agroforestry and monoculture system on post-coal mining revegetation land. The agroforestry system produced higher leaf length and canopy width than monoculture system. However, the monoculture system produced higher tillers number per clump than agroforestry system. The G2 variety produced higher the tillers number per clump, leaf length and canopy width of lemongrass than Sitrona 2 Agribun variety. The G2 variety was more suitable in both agroforestry and monoculture planting system than Sitrona 2 Agribun variety.

\section{References}

Allo, M. K. (2016). Kondisi sifat fisik dan kimia tanah pada bekas tambang nikkel serta pengaruhnya terhadap pertumbuhan trengguli dan mahoni. Jurnal Hutan Tropis, 4(2), 207-217. https://doi.org/10.20527/ jht.v4i2.3608

Anwar, A., Nugraha., Rukmana, A. N., \& Nurahman, A. A. (2017). Pemberdayaan potensi masyarakat Desa Cimungkal Kecamatan Wado melalui wirausaha serehwangi. Jurnal Penelitian dan Pengabdian Masyarakat (Ethos), 5(2), 224-231. https://doi.org/ 10.29313/ethos.v5i2.2334

Artru, S., Garre, S., Dupraz, C., Hiel, M. P., Frayret, C. B., \& Lassois, L. (2017). Impact of spatio-temporal shade dynamics on wheat growth and yield, perspectives for temperate agroforestry. European Journal of Agronomy, 8(2), 60-70. https://doi.org/10.1016/j.eja.2016.10.004

Azizah, N., Wijayanto, N., \& Wirnas, D. (2019). The growth and rooting dimensions of the local and Solomon Albizia in the agroforestry system. Biodiversitas, 3(10), 3018-3023. https://doi.org/10.13057/biodiv/d201034

Bisoi, S. S., Mishra, S. S., Barik, J., \& Panda, D. (2017). Effects of different treatments of fly ash and mining soil on growth and antioxidant protection of Indian wild rice. Journal of Phytoremediation, 19(5), 446-452. https://doi.org/10.1080/15226514.2016.1244164

Buta, M., Blaga, G., Paulette, L., Pacurar, I., Sorca, S., Borsai, O., ..., \& Negrusier, C. (2019). Soil reclamation of abandoned mine lands by revegetation in Northwestern part of Transylvania: A40-year retrospective study. Sustainability, 11(12), 3393. https://doi.org/10.3390/ su11123393

Cardinael, R., Chevallier, T., Cambou, A., Beral, C., Barthes, B. G., Dupraz, C., ..., \& Chenu, C. (2017). Increased soil under agroforestry: A survey of six different sites in France. Agriculture, Ecosystems, \& Environment, 236, 243-255. https://doi.org/10.1016/ j.agee.2016.12.011

Caron, B. O., Pinheiro, M. V. M., Korcelski, C., Schwerz, F., Elli, E. F., Sgarbossa, J., \& Tibolla, L. B. (2019). Agroforestry systems and understory harvest management: the impact on growth and productivity of dual-purpose wheat. Anais da Academia Brasileira de, 91(4), e20180667. https://doi.org/10.1590/00013765201920180667

Chandrawanshi, S. (2016). Impact of intercropping on growth productivity and oil yield of patchouli (Pogostemoncablin: Benth.) under multitier Acacia mangium based agroforestry system in Chhattisgarh Raipur, New Delhi [thesis]. New Delhi: Indira Gandhi 
Krishi Vishwavidyalaya.

Daswir, Yudarfis, Rubaya, Y., \& Nelvi. (2009). Teknik introduksi tanaman serehwangi untuk lahan konservasi. Laporan teknis penelitian tahun anggaran 2009. Bogor: Balai Penelitian Tanaman Obat dan Aromatik.

Hairiah, K., Sardjono, A. M., \& Sabarnurdin, S. (2002). Introduction to agroforestry. Bogor: World Agroforestry Center Southeast Asia (ICRAF).

Hamed, E. S., Toaima, W. I. M., \& El-Shazly, M. (2017). Effect of planting density and bio fertilization on growth and productivity of Cymbopogon citratus (DC.) Stapf. (Lemongrass) plant under Siwa Oasis conditions. Journal of Medical Plants Studies, 5(2), 195-203.

Hardjowigeno. (2003). Ilmu tanah. Jakarta: PT Melton Putra.

Juliarti, A., Wijayanto, N., Mansur, I., \& Trikoesoemaningtyas. (2020). Analisis rendemen minyak serehwangi (Cymbopogon nardus L) yang ditanam dengan pola agroforestri dan monokultur pada lahan revegetasi pasca tambang batubara. Jurnal Sylva Lestari, 8(2), 181-188. https://doi.org/10.23960/ js128181-188

Kaur, R., Sharma, M., \& Puri, S. (2017). Impact of tree management on the growth and biomass production behavior of Zea mays under an agroforestry system in Solan District of Himachal Pradesh. Imperial Journal of Interdisciplinary Research, 3(2), 502-510.

Kebede, B. L., \& Chala, M. (2016). Influence of plant population density on growth and yield of lemongrass (Cymbopogon citratus L.) at Wondo Genet, South Ethiopia. Journal of Agriculture Science Research, 4(3), 76-84. https://doi.org/10.14662/ARJASR2016.006

Lestari, D. A., Fiqa, A. P., Fauziah., \& Budiharta, S. (2019). Growth evaluation of native tree species planted on the post-coal mining reclamation site in East Kalimantan, Indonesia. Biodiversitas, 20(1), 134-143. https://doi.org/10.13057/biodiv/d200116

Lubis, D. S., Hanafiah, A. S., \& Sembiring, M. (2015). Pengaruh $\mathrm{pH}$ terhadap pembentukan bintil akar, serapan hara $\mathrm{N}, \mathrm{P}$ dan produksi tanaman pada beberapa varietas kedelai pada tanah inseptisol di rumah kaca. Jurnal Agroekoteknologi, 3(3), 1111-1115.

Maiti, D., \& Prasad, B. (2016). Revegetation of fly ash- a peer review with emphasis on grass-legume plantation and bioaccumulation of metals. Applied Ecology and Environmental Research, 14(2), 185-212. https://doi.org/10.15666/aeer/1402_185212

Mashud, N., \& Manaroinsong, E. (2104). Pemanfaatan lahan bekas tambang batubara untuk pengembangan sagu. Bulletin Palma, 15(1), 56-63.
Matsumoto, S., Shimada, H., Sasaoka, T., Miyajima, I., Kusuma, G. J., \& Gautama, R.S. (2017). Effect of acid soils on plant growth and successful revegetation in the case of the mine site. In S. Oshunsanya (Ed.), Soil pH for nutrient availability and crop performance. IntechOpen. https://doi.org/10.5772/intechopen.70928

Mensah, A. K. (2015). Role of revegetation in restoring the fertility of degraded mined soils in Ghana: A review. International Journal of Biodiversity and Conservation, 7(2), 57-80. https://doi.org/10.5897/IJBC2014.0775

[MoA] Ministry of Agriculture. (2016). Ministry of Agriculture Decree Number 81/Kpts/KB.020/1/2016 concerning the Release Sitrona 2 Agribun Clones as Superior Varieties. Jakarta: Ministry of Agriculture.

Mueller, L., Schindler, U., Mirschel, W., Shepherd, T. G., Ball, B. C., Helming, K., \& Wiggering, H. (2010). Assessing the productivity function of soils. A review. Agronomy for Sustainable Development, 30, 601-614. https://doi.org/10.1051/agro/2009057

Nawaz, M. F., Bourrie, G., \& Trolard, F. (2013). Soil compaction impact and modeling, A review. Agronomy for Sustainable Development, 33, 291-309. https://doi.org/10.1007/s13593-011-0071-8

Ningrum, D. K. B., Wijayanto, N., \& Wulandari, A. S. (2018). Pertumbuhan sengon dan produksi padi gogo pada taraf pemupukan $\mathrm{P}$ yang berbeda dalam system agroforestri. Jurnal Silvikultur Tropika, 10(1), 1-6.

Nurdianti, H., Efendi, E., \& Gunawan, H. (2019). Respon pertumbuhan dan produksi tanaman sereh (Cymbopogon citrus) terhadap aplikasi pupuk NPK Tawon dan ZPT Hantu. Bernas Agriculture Research Journal, 15(3), 6-21.

Pandey, V. C., Prakash, P., Bajpai, O., Kumar, A., \& Singh, N. (2014). Phytodiversity on fly ash deposits: Evaluation of naturally colonized species for sustainable phyto restoration. Environmental Science and Pollution Research, 22(4), 2776-2787. https://doi.org/10.1007/ s11356-014-3517-0

Pandey, V. C., \& Singh, B. (2012). Rehabilitation of coal fly ash basins: Current need to use ecological engineering. Ecological Engineering, 49, 190-192. https://doi.org/10. 1016/j.ecoleng.2012.08.037

Rahman, M. A., Lee, S. H., Ji, H. C., Kabir, A. H., Jones, C. S., \& Lee, K. W. (2018). Importance of mineral nutrition for mitigating aluminum toxicity in plants on acidic soils: Current status and opportunities. International Journal of Molecular Sciences, 19(10), 3073. https://doi.org/ 10.3390/ijms19103073

Rosman, R. (2012). Kesesuaian lahan dan iklim tanaman serehwangi. Bunga rampai inovasi tanaman atsiri. Jakarta: Ministry of Agriculture. 
Setiadi, Y., \& Adinda. (2013). Evaluasi pertumbuhan pohon di lokasi revegetasi lahan pasca tambang PT. Vale Indonesia Tbk Soroako, Sulawesi Selatan. Jurnal Silvikultur Tropika, 4(1), 19-22.

Setyaningsih, L., Wulandari, A. S., \& Hamim, H. (2018). Growth of typa grass (Typha angustifolia) on gold-mine tailings with the application of arbuscular mycorrhiza fungi. Biodiversitas, 19(2), 504-509. https://doi.org/ 10.13057/biodiv/d190218

Setyaningsih, L., Dikdayatama, F. A., \& Wulandari, A. S. (2020). Arbuscular mycorrhizal fungi and rhizobium enhance the growth of Samanea saman (trembesi) planted on gold-mine tailings in Pongkor, West Java, Indonesia. Biodiversitas, 21(2), 611-616. https://doi.org/10.13057/biodiv/d210224

Shukor, N. N., Hamid, H. A., Abdu, A., \& Ismail, M. K. (2015). Effects of soil compaction on growth and physiological characteristics of Azadirachta exelsa seedlings. American Journal of Plant Physiology, 10(1), 25-42. https://doi.org/10.3923/ajpp.2015.25.42

Simarangkir. (2000). Analisis riap Dryobalanops lanceolata Burck. pada jalur yang berbeda di hutan koleksi Universitas Mulawarman Lempake, Kalimantan Timur. Frontir, 32 .

Soendjoto, M. A., Dharmono, Mahrudin, Riefani, M. K., \& Triwibowo, D. (2014). Plant species richness revegetation on the reclaimed coal mine land of PT. Andaro Indonesia, South Kalimantan. Jurnal Manajemen Hutan Tropika, 20(3), 150-158. https://doi.org/ 10.7226/jtfm.20.3.150

Suci, C. W., \& Heddy, Y. B. S. (2018). Pengaruh intensitas cahaya terhadap keragaaan tanaman of puring (Codiaeum varigetum). Jurnal Produksi Tanaman, 6(1), 161-169.

Sujianto, Sukamto, \& Hadi, S. (2018). Prospek ekonomi pengembangan tanaman seraiwangi (Cymbopogon nardus L) untuk lahan kering dan konservasi tanah. In Optimasi pemanfaatan lahan kering untuk peningkatan kesejahteraan petani (pp. 613-627). Banjarmasin: Balai Penelitian dan Pengembangan Pertanian.

Sulaswatty, A., Abimanyu, H., \& Rusli, M. S. (2019). Menelusuri jejak minyak serai wangi. In A. Sulaswatty, M. S. Rusli, H. Abimanyu, \& S. Tursiloadi (Eds.), Quo vadis minyak serai wangi dan produk turunannya (pp. 1-12). Jakarta: LIPI Press.
Sukamto, Djazuli, M., \& Suheryadi, D. (2011). Serehwangi (Cymbopogon nardus) sebagai penghasil minyak atsiri, tanaman konservasi dan pakan ternak. In E. Karnawati, B. Prastowo, D. Soetopo, \& R. S. Hartati (Eds.), Inovasi teknologi mendukung peningkatan nilai tambah, daya saing, dan ekspor perkebunan (pp. 175-180). Bogor: Pusat Penelitian dan Pengembangan Perkebunan.

Suryani, E., \& Dariah, A. (2012). Peningkatan produksi tanah melalui sistem agroforestri. Jurnal Sumberdaya Lahan, 6(2), 101-109.

Suryani, E., \& Nurmansyah. (2013). Penampilan beberapa klon unggul seraiwangi pada dua agroekologi berbeda di Sumatera Barat. Buletin Penelitian Tanaman Rempah dan Obat, 24(2).

Susanto, M., \& Baskorowati, L. (2018). Pengaruh genetik dan lingkungan terhadap pertumbuhan sengon (Falcataria moluccana) ras lahan jawa. Jurnal Bioeksperimen, 4(2), 35-41. https://doi.org/10.23917/ bioeksperimen.v4i2.6883

Syukur, C., \& Trisilawati, O. (2019). Varietas unggul serehwangi, teknologi budidaya dan pasca panen. Bogor: [Balittro] Balai Penelitian Tanaman Obat dan Aromatik.

Tarigan, P. L., Tohari, \& Suryanto, P. (2019). Physiological response from upland rice varieties to the furrow with organic matter on agroforestry systems with Eucalyptus (Melaleuca leucadendra L). Caraka Tani: Journal of Sustainable Agriculture, 34(2), 223-231. https://doi.org/ 10.20961/carakatani.v34i2.29786

Torralba, M., Fagerholm, N., Burgess, P. J., Moreno, G., \& Plieninger, T. (2016). Do European agroforestry systems enhance biodiversity and ecosystem services? A metaanalysis. Agriculture, Ecosystems and Environment, 230, 150-161. https://doi.org/10.1016/j.agee.2016.06.002

Verma, S. K., Singh, K., Gupta, A. K., Pandey, V. C., Trivedi, P., Verma, R. K., \& Patra, D. D. (2014). Aromatic grasses for phyto management of coal fly ash hazards. Ecological Engineering, 73, 425-428. https://doi.org/ 10.1016/j.ecoleng.2014.09.106

Zulkarnain, Joy, B., Tuhpawana, P., \& Prawira, I. (2014). Soil erosion assessment of the post-coal mining site in Kutai Kartanegara District, East Kalimantan Province. International Journal of Science and Engineering, 7(2), 130-136. https://doi.org/10.12777/ijse.7.2.130-136 